\title{
NIKETCHE: A STORY OF SUCCESS
}

\author{
Ana Margarida Dias Martins \\ The University of Manchester
}

\section{"Todo o mundo lê e fica feliz." Paulina Chiziane}

Niketche: Uma História de Poligamia (Chiziane 2002) may be Paulina Chiziane's fourth novel, but it has done more than any of Chiziane's other books to define the "spirit" of her fiction. ${ }^{1}$ From among Chiziane's five published novels, Niketche is by far the most popular. ${ }^{2}$ What are the reasons for its success? Niketche possesses all the ingredients to succeed: it is a novel accessible to readers of different competencies; it is particularly well designed to engage urban Mozambicans and non-Africans interested in exploring various practices associated with marriage and sexuality; it shows a great geographical, cultural and ethnic range; it is a José Craveirinha prize winner; ${ }^{3}$ it is provocatively genderconscious; and it is also undoubtedly funny.

However, the thesis pursued in this article is that Niketche's popularity owes more to the limits its internal exotic charge draws to provocation than to its provocative taboo-lifting undertone. I argue that Chiziane's ambitious attempt to question received patriarchal representations of ethnic and sexual difference in postcolonial Mozambique

\footnotetext{
${ }^{1}$ Niketche will henceforth be used to refer to Chiziane's novel.

${ }^{2}$ While Chiziane's other novels reached a second edition four (or more) years after they were published by Portuguese publisher Caminho, Niketche was up for a third edition in 2004, only two years after it was published (2002), despite the fact that it is one of Chiziane's most expensive novels (15.75 Euro on Caminho's website) together with Ventos do Apocalipse.

${ }^{3}$ One year after it was published (in Portugal), Paulina Chiziane's Niketche: Uma História de Poligamia was awarded an important literary distinction in Mozambique: the José Craveirinha literary prize, understood as Mozambique's most prestigious "career prize." See Martins and Tavares $2008 \mathrm{c}$.
} 
ends up re-affirming patriarchal power by drawing on an "internal exotic" that stimulates the consolidation of a southern Mozambican female norm. The novel's success is intimately related with Chiziane's contestation of power (in all its forms), but only "up to a point." This is another important feature of Chiziane's identity as a writer, one that, together with her quest for anthropological authority, may be connected with an effort to achieve legitimisation as a writer in and beyond Mozambique. I elaborate on this perspective by examining the extent to which the novel carries leftovers of a European patriarchal cognitive control over the Mozambican land on the level of the narrator's anthropological authority, which can be historically traced back to a set of reading and writing practices spread by a group of protestant missionaries in late-nineteenth-century and early-twentiethcentury south-east Africa. As argued by Patrick Harries in Junod e as Sociedades Africanas: Impacto dos Missionários Suíços na África Austral, these practices were informed by an "anthropology of rescue" (Harries 2007: 294). As a close examination of Niketche's internal exotic will reveal, the presence of Junod's "anthropology of rescue" works as a vital dimension of Chiziane's anthropological authority as a writer. In Niketche, national identity is built in terms of regional alignments, which have been historically calibrated by confrontation with an Outside - a male European-based aesthetic experience that was once responsible for the anthropological and literary creation of a non-Portuguese "African voice" (Harries 2007).

In what follows, I tie the acknowledgment of this anthropological inheritance to an understanding of the novel's development of an "internal exotic" in relation to the northern regions of Mozambique, which arguably sets limits to the problematisation of gender power relations in the context of the narrative's representation of ethnic and gender identities. My point of entry into the internal exotic in Niketche is Rami's rhetoric of "self-projection," according to which physical similarities and psychological affinities between her (a southern woman) and the other female characters (from the centre/north) are described so as to 
evoke a sense of estrangement and defamiliarisation in relation to the latter. In order to assess how far Rami's ironic mimicry goes in the critique of the nation as a male construct, I focus on the relationships established between Rami and her women "rivals." As I wish to suggest, underneath the women's friendship lies a hierarchical encoding of unequal power relations which ultimately reinforces stereotypical perceptions of cultural difference in Mozambique in sexualized terms. It is via Rami's complicity with a southern patriarchal order-visible in her relationship with her "others"- that the internal exotic is revealed throughout the novel. The internal exotic is also reinforced according to the novel's focus on the supposed spatial "otherness" of the north, achieved by drawing on the northern female characters' marginalized life in the south, as opposed to their previously (supposedly) blissful life in the north. The creation of spatial otherness in this case reinforces a sense of temporal otherness as well, setting the northern exotic (or otherworldly) gender and sexual bliss in the Past, in stark opposition to the reality of Now, which is spatially set in the south (Maputo), where the novel takes place. So as to stress the extent to which Rami's polygamous experiment contributes to reproducing the phallic singularity of the nation, I make a parallel between Niketche and Aristophanes' comedy Lysistrata (Aristophanes 411) to show both texts' similarities in their peaceful - and apparently disruptive - takeovers of male power by women through sex. I conclude with the thought that the secret of Niketche's (and also Chiziane's) success both in Mozambique and outside depends largely on an effort to contest that is never entirely materialized. Despite (or perhaps because of) Chiziane's self-marketing as the female enfant terrible of contemporary Mozambican literature, and contrary to the author's claims about her marginal status in her country, Chiziane is gaining popularity as a writer within Mozambique's mainstream culture. This is due to her novels'-particularly Niketche's-bold exploration of taboo issues such as women's sexuality within well defined boundaries, both inviting and frustrating full contestation of power. 
An "untouched" north? Junod's "anthropology of rescue" revisited

The imagination of a plural nation in Niketche corresponds to the author's most successful negotiation to date of symbolic forms of recognition and legitimization as a Mozambican woman writer. Like no other, it draws on an authorial performance of anthropological authority over the Mozambican land. Anthropological "power" is a key element in Chiziane's identity as a writer, one that appeals strongly to both Mozambicans and west Europeans. On the one hand, as Hilary Owen rightly notes in Mother Africa, Father Marx, Niketche also exemplifies, better than any other novel, the author's locally grounded critical intentions, marking "Chiziane's most explicit discussion to date of gender difference in the national narrative and women's rejection of transcultural ambivalence as a gloss for sexual double standards" (Owen 2007: 201). But, on the other, Niketche also offers considerable insight into the writer's creative engagement with Europe's longstanding "appetite" for the "anthropological exotic" (Huggan 2001), proving that it is alive and well in the postcolonial lusophone context from which (and to whom) Chiziane writes.

The expression "anthropological exotic" was coined by Graham Huggan in The Postcolonial Exotic: Marketing the Margins, and it describes a mode of perception and consumption that "sees" African literature as a "window onto a richly detailed and culturally specific, but still somehow homogeneous - and of course readily marketable-African world" (Huggan 2001: 37). According to Huggan, the anthropological exotic describes both a mode of perception and of consumption of cultural difference. Through this perceptual framework, the unitiated reader is offered some information about foreign cultures and is given the impression that he can have access to the text, and by extension, to the foreign culture itself. The anthropological exotic therefore depends on the elaboration of a world of difference that conforms to often crudely stereotypical Western exoticist 
paradigms and myths" (37), such as "primitive culture" and "magical practices."

The "anthropological exotic," as defined by Huggan in 2001, reflects ideas already contained in a book first published in 1912 that has become a classic in anthropology. In The Life of a South African Tribe, Henri-Alexandre Junod emphasizes a set of basic notions about Africa that generations of anthropologists to come would find very hard to shake off (Junod 1927). As Patrick Harries argues in Junod e as Sociedades Africanas, Junod's intellectual inheritance "não só teve importantes consequências políticas para a África do Sul, mas também reflectiu e reforçou muitas das ideias sobre as quais foi construída a compreensão geral sobre África" (Harries 2007: 294). Headed by Junod, a group of Protestant missionaries in late-nineteenth-century southeast Africa elaborated a world of difference that offered Switzerland the image of their own level of development. By describing Africa as a place "onde não existiam os entraves da civilização, como um continente de experimentação cultural onde o instinto e a alma triunfavam sobre o intelecto apático" (Harries 2007: 57), the Swiss missionaries cultivated a positive image of their own country that fought for the emancipation and illumination of supposedly "pagan" and "superstitious" peoples overseas. Describing Africa as a premodern, deeply rural and therefore "authentic" region, untouched by the evils of civilization and progress, helped Switzerland to feel intensely Swiss. Quite simply, Switzerland was what Africa was not and Africa what Switzerland had once been. To Harries, this Manichean perceptual framework was the result of Junod's "antropologia de resgate" (Harries 2007: 294). For the sake of projecting the image of a primitive, untouched Africa, Junod would, for instance, never mention the reality of Mozambican workers in South Africa, or dwell on the stories of Mozambicans who moved to the cities in his ethnographic reports. Instead, he concentrated on describing (or rescuing from oblivion) small villages, and photographed well-contained environments where objects considered "modern," like chairs and books, were meticulously absent. 


\section{Ana Margarida Dias Martins}

The generation of Junod systematized the cultures they found according to Western-based knowledge systems to affirm their own missionary project (Harries 2007: 3). For example, they studied, learned and wrote down the language and the customs of a group of people they later named Tsonga (Harries 1989). ${ }^{4}$ By formulating literacy from an evolutionist perspective, the Swiss missionaries built an African "ethnic voice" (Harries 2001). As pointed out by Patrick Harries (Harries 2007), Severino Ngoenha (Ngoenha 1999) and Teresa Cruz e Silva (Cruz e Silva 2001) in their studies dedicated to the presence of the Swiss missionaries in Mozambique, this African "ethnic voice" was also a deeply southern and a deeply male construct, contributing to the shaping of a Tsonga nationalism (Ngoenha 1999), and to the formation of a gendered and political consciousness (Cruz e Silva 2001 and Owen 2007) in southern Mozambique.

The relationship between the anthropological effort of the Swiss missionaries and the development of contemporary modes of production, reception and consumption of lusophone African literature (in Africa and elsewhere) has not yet been adequately addressed. Here, I would like to focus on that relationship (in the context of postcolonial Mozambique) by drawing on the concept of the internal exotic. Directing my reading of Niketche is the argument according to which the novel is being successfully consumed in Mozambique and abroad in part due to its representation of an internal exotic. Understood as a perceptual lens historically linked to Junod's anthropology of rescue and inescapably deriving from a specific Mozambican gendered experience of colonization, the internal exotic is here defined as an Afro-centric postcolonial repoliticisation of a Western colonial concept: the anthropological exotic. The internal exotic

4 As Patrick Harries notes in "Exclusion, classification and internal colonialism: the emergence of ethnicity among the Tsonga-speakers of South Africa," "Tsonga identity has thus emerged as the product of a variety of forces. These include the European obsession with social classifications; a government policy that attempted to divide Africans along ethnic lines; and, as well, an awareness expressed by many Africans of the numerous benefits that accrued from the mobilization of people among ethnic lines" (Harries 1989: 83). 
provides a (sexual) "inside other" against which mainstream Mozambique can measure itself. Through this lens, women from the central and northern regions of Mozambique are "seen" (and their sexual difference "filtered") as the internal female "other." Implicated in the internal exotic are exoticised constructions of female sexuality in postcolonial Mozambique. The internal exotic affects women throughout Mozambique differently, since the production of a national image according to the exoticisation of the north in sexual terms stimulates the creation of a southern female-norm. Through this lens, the north holds "desirable" features that are used to define what mainstream "Mozambicanness" supposedly is according to the north's fetishised "difference." My discussion of the internal exotic, at work in Chiziane's Niketche, acknowledges that African forms of female subordination through exoticisation differ considerably from European forms of subordination of Africa (in the feminine) through the conventions of the exotic: while the anthropological exotic is mainly shaped by colonial and neocolonial Western male patriarchy, African domestic processes of female exoticisation such as the internal exotic are more complex, shaped by both colonial male patriarchy and developed by a domestic colonized male patriarchy-the beneficiaries of Junod's intellectual inheritance who formed the political elite after independence.

Despite the fact that the theoretical notion of the internal exotic in Chiziane's literary output has not yet been specifically addressed by critics, the matter of the supposed "otherness" of Mozambique's north has been discussed, particularly in the context of the matrilineal/patrilineal scripts of Mozambique (in the north and south respectively). Although ethnic boundaries are very hard to trace due to Portuguese colonialism, gender roles and polygamy help define a significant cultural border between the north and the south of Mozambique. Until the end of the nineteenth century, the south of Mozambique was pre-capitalist, patrilineal and mainly polygamous, while the north was mainly matriarchal, matrilineal and monogamous. With Christianity, colonialism and Marxism being introduced in the south, the 
practice of polygamy began to be questioned. Jean Davison addresses the problematic of the matrilineal script and argues, in Gender, Lineage and Ethnicity in Southern Africa that 'those subscribing to matriliny become the 'other,' juxtaposed in ideology and practice to the majority subscribing to patriliny. In a sense, subscribing to matriliny is similar to being left-handed in a right-handed world, but with economic consequences" (Davison 1997: 190). Davison's observation that matrilinity is often given as a reason "for holding back progress" in the north (Davison 1997: 190) justifies my understanding of the internal exotic as the lens through which the north is translated, via an aestheticisation of matrilinity, as an "authentic" region, untouched by the evils of civilisation and development.

In "Niketche: O Existencialismo no Feminino," Lourenço do Rosário also points to Chiziane's "discovery" of the north as an example of the author's oversimplified view of Mozambique's ethno-cultural multiplicity: "A mulher do norte vista demasiadamente eufórica, e a do sul demasiadamente disfórica tal como está no romance é perfeitamente permitido no plano da ficção, mas falseia as referências culturais e antropológicas que servem de referência ao universo romanesco" (Rosário 2007: 118). Rosário's reference to Chiziane's "discovery" of the north in terms of a gendered oversimplified view of Mozambique, on the other hand, credits the hypothesis that the internal exotic subscribes to a gender-ethnicity axis. These references motivate me to take up the expression "internal exotic" as the theoretical notion behind my reading of Niketche.

\footnotetext{
${ }^{5}$ In Mother Africa, Father Marx, Owen uses the expression "gender exoticism" understood as a consequence of the historical gendering of the oral/literacy divide which has "shadowed and shaped women's integration into the institutions of cultural production and literary criticism through the medium of Portuguese" (Owen 2007: 22) in Mozambique. The expression refers to a specific gender politics at work underneath the opposition between the literate and oral culture in the Mozambican national imaginary which emphasizes women's "otherness" through which male projections come to be narrated. The expression "internal exotic" used in my article refers to a different divide (gender/ethnicity axis),
} 
Speak to the hand, because the fingers aren't listening (says Rami)

Niketche is set in Maputo, several years after the first democratic elections. Departing from the cultural differences between the north and the south of the country, the novel stages the mechanisms and the rhetoric of masculine impunity in the southern patriarchal Mozambican societies, to discuss the role of "difference" (gender, sexual and ethnic difference) in the formation of the national imaginary. In an ironic mimicry of the political processes that invented Mozambique as a "colony" and later as a unified "nation" from the south, Niketche introduces four female charactersone from the south and three from the centre and north of the country-described from the point of view of the southern woman, Rami. The author maps out the influence of Christianity and Portuguese colonialism in the south of Mozambique through reference to Rami. When discussing different practices associated with marriage and sexuality with a love advisor, Rami declares: "o meu pai é um cristão ferrenho, de resto a pressão do regime colonial foi muito mais forte no sul do que no norte" (39). Being from the south, Rami is completely alien to initiation rites, the payment of lobolo and polygamy, due to missionary work and colonial power. ${ }^{6}$ Similarly to what happens to Vera in relation to the witchcraft practices of her husband's secret life in Chiziane's previous novel O Sétimo Juramento (2000), Rami's opinion on Mozambican marriage practices is that of an outsider.

according to which women from the northern regions of Mozambique are constructed as the excessively sexual female "other."

${ }^{6}$ The presence of Portuguese travellers and protestant missionaries particularly in the south of Mozambique, who strongly criticised local practices of bridewealth, as well as polygyny and widow inheritance, contributed to introducing other marriage codes that began to gain prominence in national life throughout the twentieth century. As Kathleen Sheldon argues in Pounders of Grain: A History of Women, Work and Politics in Mozambique, unhappily married women began to respond to missionaries when they felt oppressed by the marriage systems of southern Mozambique, and when that was the case, they often converted to Christianity in mission centres. See Sheldon 2002: 28. 
She is married to Tony, a Changaan from the south, officially monogamous, Catholic and a high-ranked police officer who maintains several sexual relationships with other women. One evening, mindful of the existence of her family "opponents," Rami observes that the image reflected in her bedroom mirror is not that of her own body, but the image of another "self"- another woman who looks like her but is not her. While she observes the multiplication of her family by four other families, she experiences her own personal reformulation as a plural body. Throughout the narrative, the nation is also significantly re-built as a plural body, or as a "national-body-with-strangers-within," thus establishing a parallel between body, family and nation. The novel narrates the confrontation with these "strangers"-female subjects whose presence (in the body/family/nation) questions the way in which the masculine "I" (but also feminine "me") inhabit and define the nation-space.

Tired of being betrayed by her husband, Rami decides to meet her "rivals." The women's spatial segregation in Maputo - as the "victims" of a hidden form of polygamy - reinforces the spatial "otherness" of their original northern background. Julieta (Ju) comes from Inhambane (south), Luísa (Lu) is a Sena from Zambézia (centre/north), Saly is a Maconde from Cabo Delgado (north), and Mauá Saulé is a Macua and comes from Nampula (north). Tony's other lovers include Eva, from Palma (north) and Gaby (of unknown origin). Finally, there is the young Saluá from Niassa (a nhanja), the "final drop" in the women's revenge against Tony. After meeting her "rivals," Rami initiates, in Owen's terms, "a modified, urban form of polygamous union" (Owen 2007: 204) so as to "save" the other women from marginal, non-conjugal life. ${ }^{7}$ Together, they form a hand ("Somos cinco. Unamo-nos num feixe e formemos uma mão" [107]), and the union effectively empowers $\mathrm{Ju}, \mathrm{Lu}$, Saly and Mauá. The women's strategic performance of polygamy's values and rules, which include timetabling Tony's sexual duties and encouraging him to take more wives,

\footnotetext{
${ }^{7}$ This modified urban form of polygamous union suggests flexibility in the application of customary law in Mozambique.
} 
contributes to diminishing Tony's power over them. The female performance of the centre produces a critique of the phallic centre as emptiness, as "fogo de palha na última chama" (62). By joining in Rami's project of establishing a polygamous family, the women enact their personal revenge against Tony's adulterous life. ${ }^{8}$

But Rami's strategic manipulation of the polygamous union, although considerably favouring her rivals' own empowerment, subtly reinforces a power disparity in what northern and southern women are concerned. For instance, the flexibility that characterises the new polygamous family does not affect Rami's traditional power as the "first wife.", Within the modified family structure, Rami's position of power as Tony's "official" wife is ambiguously left unquestioned, thus enhancing her possibilities to manipulate the other women in her own project of revenge against her husband. Furthermore, Rami's decision to officially open the gates of her home to these women by symbolically pulling the northern margins in rehearses a subtler performance of the centre by Rami herself. The first wife's all-inclusive new family project does not entirely collapse the distance between her and the other women. On the contrary, drawing them in contributes not only to granting them social visibility, but also to render more visible the insurmountable (cultural and sexual) difference that distinguishes her from them. Rami's "gift" of visibility to these women thus hides a southern subtext of power, according to which the supposedly sexually adult (the northern women) are given a socially visible life by the sexually uninitiated Rami. The subtext on power is clearly noted by the victim of the "hand," Tony, who denounces the other women's perceived lack of voice in the new polygamous relationship: "Julgam que têm direitos e voz, mas não passam de patos mudos" (166).

\footnotetext{
${ }^{8}$ As pointed out by Sandra Campos in "Corporeal Identity: representations of female sexuality and the body in the novels of Paulina Chiziane," the author has declared (in an interview to Patrick Chabal) that real polygamy is very different from adultery because, for instance, it does not allow there to be illegitimate children. See Campos 2004: 150.

${ }^{9}$ In traditional polygamy, the first wife rules over all the others.
} 
In fact, the wives' newly found visibility is exotically appealing, catering to the (supposedly sexually uninitiated) southerners' needs. As the "internal others" from the north, their exotic appeal will legitimize Rami's "sameness" (as a woman from the south and the "first wife") in the newly made polygamous family. The relationships of solidarity and friendship established between Rami and her "rivals" are governed by a subtext on difference, visible in the process through which the "I" absorbs the difference of the "other" (for her own empowerment), which significantly reinforces the north as an exotically marked space through sex. In other words, the attempt to break Mozambique's myth of national unity in Niketche is problematically promoted by the transgressive value of Rami's personal fantasy-her rhetoric of self-projection - or her power to project her "self" onto these female "others." This includes the narcissist fantasy of Rami as "voyeur" of her "self" in these women who look like her, and who are in situations similar to hers.

The striking (physical and emotional) similarities between them only apparently destabilizes the otherwise "stable" line drawn between the "self" and the "other"-a strategy of destabilization already hinted at during the initial episode depicting Rami in front of her bedroom mirror. Despite the marginality of their relationships with Tony, the other women do not satisfy Rami's initial expectations of asymmetry: they are strong women, they live comfortably and they even resemble herself physically. But the apparent destabilisation of the "self" only reinforces received notions of "otherness," revealing the extent to which northern sexual difference is culturally and socially consensual in Mozambique. The internal exotic works on the level of Rami's "rhetoric" of self-projection, according to which an apparently destabilised "self" reinforces her identity by means of the sexual difference of a faraway north transformed into a platform for self-projection.

For instance, the desire to connect with Julieta is quickly transformed into a platform for Rami's self-projection: "Conheço a amargura deste choro e o calor deste fogo. Emociono-me. Solidarizo-me" (26). Although she tries to 
make a distinction between Julieta's story and her own, Rami faces the repetitiveness of the situations. Being from Inhambane, Julieta presents a specifically different case of self-projection for Rami. She is tendentiously portrayed in negative terms as a sad woman, called "a enganada" (60) by Rami. She and Rami are the only women from the south in the group, and she contributes to amplifying the "Sameness" of the southern woman epitomized by Rami, as opposed to the "otherness" of the northern women. Julieta's function in the narrative is similar to that of the mirror in Rami's bedroom: while the mirror offers Rami the image of what she wishes to become, Julieta presents the living image of what Rami is. Together, they embody the antithesis of the northern women: "Deste grupo, as mulheres naturais somos eu e a Ju" (179). As the reference to "mulheres naturais" clearly shows, the novel's rhetoric of self-projection has the effect of immediately recognizing women from the south as the norm, while applying the super-natural (or ideal) tag to those "other" women coming from the north.

The rhetoric of self-projection in the narrative exemplifies how the northern female "other" is consistently opposed to the southern woman in sexual terms. Tony significantly takes Rami's and Julieta's fidelity for granted, and these women's betrayal will hurt him the most, because he does not expect them - they are not supposed to behave that sexually. Similarly, Rami feels Julieta's pain as if it were her own when she finds out that Tony is betraying her with another woman called Luísa, a Sena from Zambézia (centre/north). Both Rami and $\mathrm{Ju}$ are from the south and they know they cannot "compete" with Lu. They can either oppose her-and be defeated - or join her-and (sexually) learn from her. This exemplifies how the construction of the female "other" in the narrative is excessively sexualized not only by southern men, such as Tony, but also by southern women like Rami. With Luísa, Rami wishes not to fight but to learn from her how to seduce men. But her search for the other's "otherness" leads Rami to face her own "sameness": "O rosto desta mulher me é familiar, muito familiar. Onde o teria visto antes?... Penso tanto que acabo descobrindo... Esta 
mulher é parecida comigo" (60). When selling clothes in the street, Rami and Luísa are taken as sisters: "Vocês são muito parecidas, pensávamos que eram irmãs de sangue" (120). The strong friendship that ends up developing between Rami and Luísa is, nevertheless, underscored by Rami's "self," which features as the prominent voice in the national dialogue throughout Niketche. The rhetoric of self-projection playfully makes the reader aware of his/her own insufficient knowledge about the north - via Rami. But, as already suggested, the effect of this rhetoric also works the other way around, reinforcing pre-existing unexamined assumptions about northern identities by exposing them. Through the other women's subjectivities, Rami rebuilds and empowers her "self," thus fixing her rivals' "selves" through her own, and under her own. The message of Niketche is uncannily similar to Junod's Manichean framework: southern Mozambique is what northern Mozambique is not, and northern Mozambique (still) is what southern Mozambique once was. The internal exotic elaborates, in the fashion of Junod's "anthropology of rescue," a world of difference up north that offers back the image of the southern world, thus helping Rami - and the reader - to feel intensely what Mozambicanness really is (the intensity of that feeling being directly connected to the south as the nation's core).

This is why Tony's wives travel up north when they go in search of another woman capable of confirming the heterogeneity of Tony's home - and of the nation - through her difference: "Viajamos para o norte onde finalmente encontramos a mulher ideal" (316). As the "mulher ideal" (316), Saluá is the final ingredient in Rami's revenge against Tony. Through Saluá, and despite Chiziane's irony in her depiction of a unified, female difference fetishised by the male southern gaze, Rami confirms her central position by projecting onto the young woman the positive role of the serpent: "O papel de serpente no paraíso Bantu lhe fica bem" (322). This is a central role in the polygamous experiment, which Rami implicitly attributes to herself, as the master of her own devised takeover of male power: "Trazer estas mulheres para aqui foi uma autêntica dança, um acto de coragem, um 
triunfo instantâneo no jogo do amor. O Tony agrediu-me e retribuí o golpe, usando a sua própria arma" (112).

Although constantly looking for more radical encounters with the other women, which also include Saly, a Maconde from Cabo Delgado, and Mauá Saulé, a Macua from Nampula, Rami ends up facing and consolidating her "self," her world, and her body. As ambassadors of the north in the south, what distinguish Tony's women is their highly sexualised identities and cultural differences, consistently dramatised in the novel in innumerable discussions about sexual and gender behaviour patterns in the south and the north. The non-erasure of cultural and sexual differences between the women does not contribute to creating a balanced environment where all women are equally perceived. Connecting the privileged status of the "first" or (legally) official wife with the south, Rami adopts a a universalist liberal feminist strategy which consists of recuperating her "self" through the other women. Her rhetoric of self-projection confirms her identity by reflecting it in what she is not. Although she reflects deeply on women's position within polygamous and monogamous societies and relationships in Mozambique, Rami does not entirely renounce her own power position as a southern woman, granting liberation to her "rivals" as the empowered southern woman's gift to her subordinates. As such, she does not necessarily undo the north-south unequal power relations on a deeper level. As far as southern female identity is concerned, meaning is not deferred through the multiple interplays of (northern) difference. It is fixed as "self" by means of the narrator's anthropological authority that homogenizes the north through the lenses of the internal exotic.

Rami's strategy: othering through inclusion

By the end of the novel, all the women have become economically independent. With the help of Rami's savings and counseling, they start their own businesses and prosper. Rami's ability to support the four wives draws attention to other kinds of differences among the women, emphasizing 
asymmetrical relationships also in terms of class. ${ }^{10}$ Finally, one by one, the women abandon Tony to start new, more balanced relationships. At the marriage of Luísa and her new partner Víctor, the women interweave a northern dance called "niketche" (a Macua dance that celebrates sexual initiation for women in the northern region of Zambézia) with the southern tale of Vuyazi (a rhonga myth about a rebellious princess that is punished by having her image imprisoned in the moon for not being a good wife) so as to celebrate the hybridization of the northern and southern cultures of Mozambique (Owen 2007: 211). Rami's retelling of the story of Vuyazi by drawing on a reconfigured niketche dance does not prevent the latter from being perceived in its own terms as the materialisation of the internal exotic in the south. Rami's celebratory retooling of both story and dance emphasizes the latter: "dançaremos de vitória em vitória no niketche da vida" (293). It is noteworthy that the term Vuyazi is not contemplated either in the glossary at the end of the novel, or in the title of the book, contrary to the term "niketche," which is half-defined in the glossary as "dança de amor (Zambézia e Nampula)", and significantly "otherised" both in the title and throughout the novel. This points to the way in which cultural knowledge about Mozambique is constructed (and to what it is constructed against).

In the end, having been betrayed by all his women, the sexually overfed Tony wishes to escape "para um mundo onde não há mulher nenhuma, sem tentações, nem amores, nem filhos. Um mundo só de homens" (329). The success of Rami's strategy of mimicking, through inclusion, Tony's national-wide love affairs, is fully dramatized in the image of a man whose only wish is to go back to the comfort zone of his mother's home. But the question remains: to what extent does Rami's experiment actually disrupt the phallic singularity of the nation through ironic mimicry? How vulnerable to recuperation is Niketche's literary oppositional value?

${ }^{10}$ As noted by Davison, "The ability to support multiple wives is often linked to status or class." See Davison 1997: 53. 
Rami's strategy of national inclusion offers itself to be read as an upside-down Mozambican version of Aristophanes' comedy Lysistrata, written in $411 \mathrm{BC}$. As a story of women's anti-war sexual boycott proposing an apparently disruptive takeover of male power by women through sex, the Greek play combines, like Niketche, sex and politics. Aristophanes' play starts with a meeting organized by Lysistrata to unite all the women from Greece under a common oath: in order to end the war, the women conspire to withhold sex, hiding inside the Acropolis while inflaming their husbands and lovers with lust, to compel them to end the war between Athens and Sparta, spread throughout Greece. Strategically using female reputation for stubbornness and malice, the women swear under a collective oath (on a wine bowl) that they will re-"open" only on the conditions Lysistrata has named, that is, only after men have left war in women's hands. As the spiritual, economic and political centre of Athens, the Acropolis is symbolically transformed into a "national-body-with-strangers-within." As in Niketche, these "strangers" are the women interested in questioning the way in which the masculine "I" inhabits and defines the nation-space. The sex strike finally begins to take effect on the men. As they walk close to the Acropolis, they suffer full erections. Others start homosexual relationships. Finally, men decide to meet with Lysistrata and discuss peace. In the end, Lysistrata comes out of the Acropolis followed by a naked woman - aptly called Peace. Bearing a likeness to Chiziane's Saluá, Peace's beauty enchants the men. Unlike Saluá, she is not rejected, because the men of Athens are "starved" sexually, not "overfed" (like Tony). While men are distracted by Peace's beauty, Lysistrata argues against the war and convinces men to reconcile.

While Lysistrata focuses on sex-strike and Niketche on sexual over-stimulation, both texts have more in common than meets the eye. Sexual boycott is a subject also mentioned in Niketche by Mauá, who tells the other women that she is accustomed to threaten Tony with sexual strikes: "Às vezes digo-lhe: se não trazes o que quero, faço greve de sexo. Vais ficar em jejum. Fecharei as minhas portas para a 
viagem no tempo. Ele fica atrapalhado e faz de tudo para me agradar" (181). Both texts were also written in the sensitive contexts proceeding military catastrophes and civic trauma. As Blake Morrison observes, Aristophanes wrote his play "[j] ust a year after thousands of young men from Athens lost their lives in a disastrous attempt to defeat Sparta's allies in Sicily - a military catastrophe and civic trauma that some have likened to the American experience in Vietnam or, now, Iraq" (Morrison 2007). Owen notes, on the other hand, that Niketche is "clearly set after the end of the postindependence war, and was published a decade after the Rome Peace Accord, and eight years after the first democratic elections" (Owen 2007: 201). Despite the relatively calm period depicted, the novel deals with the consequences of war and economic crisis in terms of the number of men "available" in the north and south of Mozambique. As Luísa tells Rami, "Venho de uma terra onde os homens novos emigram e não voltam mais. A minha mãe nunca conseguiu um marido só para ela" (57). Furthermore, in Lysistrata and Niketche, both Aristophanes and Chiziane produce a humorous treatment of a topic that tends to be regarded as "serious," strategically pushing the stories beyond the credible so that the seriousness of the message can be communicated whilst at the same time arousing laughter. While in Lysistrata, humor lies in the appearance of characters (men dressed as women, or men with enormous phalluses) and in the language used, throughout Niketche, humor hides behind the stereotypes it (re)produces. The dutiful wife, typified by Rami, exemplifies this subtle mockery, which has devastating effects for Western ideals of middle-class femininity. Moreover, humor hides - both in Lysistrata and Niketchebehind staged male centrality, weakening male symbolic authority in both texts through mockery of male agency and power. The episode where Saly invites all the women to sleep over with Tony in the same room exemplifies this mockery of male phallic power: "Hoje vais mostrar-nos o que vales, Tony - diz a Saly furibunda. - Se cada uma te realiza um pouco de cada vez, então realiza-te de uma só vez, com todas nós, se és capaz. O Tony fica atrapalhado" 
(143). Finally, another common feature between these two texts is the celebration of female power. Lysistrata celebrates female power in the lives of men, in particular the power of female skills in the untangling of the difficult situations in which men find themselves. For example, in the play's third act, while men are completely taken aback by Peace's naked body, Lysistrata lectures them on the ways in which women can build a better world by adapting their domestic knitting skills to untangle men's matters. Similarly, in Niketche, women's skills are also used to untangle their lives from Tony's economic dependency, by setting up businesses and earning a living with the financial help of Rami.

However, both in Niketche and Lysistrata, the ironic performance of the centrality of male power does not serve to disrupt it completely. Although Lysistrata entails the dramatization of the subordinate status of men to sex, the focus also goes to the sex-starved women trying in vain to escape the Acropolis and lusting after men. The older women seize the Acropolis not only to keep men from entering the sanctuary - thus freezing the funds necessary to keep the war going - but also to keep young women inside the Acropolis as hostages under Lysistrata's control: " $\mathrm{O}$ 'tis our naughty femininity, so weak in one spot" (Aristophanes 411: 706). The emphasis on men's power over women is partially extended to Lysistrata, herself a masculine, assertive character, cursing the weakness of women while pushing them to the centre of the "stage" to perform their role in her own devised takeover of male power. At this point, Lysistrata's performance leads us back to Rami's in Niketche, and to the formulation of the question: to what extent does Rami reproduce the phallic singularity of the nation in the name of an inclusion of differences?

As Sarah Ahmed writes in Strange Encounters: Embodied Others in Postcoloniality, "othering can take place by acts of inclusion within multicultural discourse" (Ahmed 2000: 97). In Niketche, no attention is given, for example, to other perceptions of "otherness" that have been growing out of real ethnic conflicts between Macuas and Macondes in the north of Mozambique. According to Conceição Osório from 
the WLSA (Women and Law in Southern Africa), ethnic problems between these ethnic groups are not only violent, but also very obvious. In an unpublished interview, Osório speaks of a barrier between these groups that is creating new images of who the "other" up north is:

Os problemas étnicos são muito duros, muito fortes. Em Cabo Delgado, eu fiquei com muito medo da situação. O problema é que é muito violento, muito claro, óbvio, entre o Macua e o Maconde há uma barreira que é... é sempre o outro, tudo o que há de mal, é o outro, o outro é o Macua ou o Maconde. (Martins and Tavares 2008b)

In Niketche, these nuances in terms of identity construction are not adequately addressed. Rami's "recuperation" of the southern female "self" is dependent on a perception of the northern woman as the sexual "other." Her reliance on unquestioned perceptions of northern matrilineal structures corresponds to Chiziane's reading of northern matrilinity largely in terms of women's power and self-worth. In Mauá's words: "A nossa sociedade do norte é mais humana. A mulher tem direito à felicidade e à vida" (175). Later, the narrator explains: "No norte, ninguém escraviza ninguém, porque tanto homens como mulheres são filhos do mesmo Deus" (175). In an unpublished interview, Chiziane develops her own view of the northern regions, which corresponds to that expressed in Niketche:

Portanto, a forma, o dia a dia como eles se relacionam [nas sociedades matriarcais], o poder que as mulheres têm, não um poder material ou intelectual, mas o espaço social que a mulher tem é uma coisa incrível. A família reune-se porque a nossa filha não tem relações sexuais. O homem é que é incompetente e ponto final. Arranja-se substituto enquanto ele resolve o problema. Que maravilha! Eu fiquei louca. (Martins and Tavares 2008a)

The idea that the northern regions of Mozambique offer a social space of bliss for women is very debatable. As Kathleen Sheldon argues in Pounders of Grain: A History of Women, Work and Politics in Mozambique, northern men still exercise considerable social power as brothers and uncles in northern matrilineal structures. From the socio-legal field, 
Osório talks about the "myth" of northern matrilinity, emphasizing, in the interview mentioned above, how the violence of war led to a "desestruturação completa que influenciou o sistema de relações de parentesco" in the north (Martins and Tavares 2008b). In stark opposition to Chiziane's discourse, Osório argues that northern women are bound to suffer much more violence than southern women because in the south relationships are still somehow regulated, while the north is now neither patrilineal nor matrilineal, only patriarchal (Martins and Tavares 2008b). Chiziane's perception of gender relations in Niketche relies heavily on an elaboration of a world of difference in the north of Mozambique, understood as an "authentic" ethnic space frozen in time, untouched by the world's transformation, and therefore the ideal "other" space for Rami's redefinition of an apparently multiple, but still deeply southern-based Mozambican national identity.

As argued this far, the internal exotic found in Niketche reveals the presence of Junod's "anthropology of rescue" as a vital dimension of Chiziane's anthropological authority as a writer. The acknowledgment of this anthropological inheritance is crucial to an understanding of the novel's limits in terms of its project to reconstruct critically gender and ethnic relations in Mozambique. The novel's success feeds on these limits, appealing strongly to (non-)Mozambicans who are not very familiar with the realities depicted in Niketche, and who wish to have them narrated in more or less plain, familiar terms. Chiziane's description of the north/south divide according to "o meu espanto, o meu encanto por essa diferença" (Martins and Tavares 2008a) in Niketche satisfies this need.

However, it should also be noted that Chiziane's emphasis on the north/south divide in Niketche is far from innocuous. Chiziane's focus on female sexuality, apart from bringing up the topic of how gender and ethnicity intertwine, powerfully shakes down the invisibility to which female sexuality has been relegated in Mozambique. According to the author, the focus on this divide brings out a new element of "Mozambicanness": "Por exemplo, eu quando olho para o 
Niketche hoje e vejo este Norte e Sul, vejo o comportamento da mulher daqui e dali, e outras coisas que não tive compreensão para escrever, eu digo assim: estes são alguns elementos que nas literaturas antigas não apareciam" (Martins and Tavares 2008a). In his study A Construção da Imagem de Moçambicanidade em José Craveirinha, Mia Couto e Ungulani Ba ka Khosa, Gilberto Matusse argues that "a moçambicanidade na literatura surge como resultado desse estranhamento, como resultado do esforço de construção de alteridade relativamente à portugalidade que está implicada na sua origem" (Matusse 1998: 190).

Chiziane's focus on the north/south divide questions Matusse's thesis. By expressing the way in which her literary production changes the configurations of Mozambican literature (reconfiguring what is meant by "Mozambicanness"), the author is not only implicitly negotiating the value of her texts according to the transformation of her themes into agents of literary self-legitimization, but she is also using her texts to question the extent to which "Mozambicanness" is to be thought of as a mere reaction against "Portugueseness." Understanding Niketche's anthropological drive (and her focus on the north/south divide) from the point of view of the specific Protestant anthropological inheritance contributes to problematising the extent to which Portugal is to act as the only Outside/Other to Mozambicans. Simultaneously, it should also be noted that it is never completely clear throughout Niketche that the ex-coloniser is in fact the poor relation in the story, due to Chiziane's continuous engagement with exoticist discourses that appeal to a Western (and obviously Portuguese) audience.

Concluding remarks: Niketche's local story of success

In sum, Niketche offers considerable insight into Chiziane's identitarian construction as a writer: as an insider/observer, Chiziane contests institutionalized power but only up to a point. Her partial contestation of power in her novels is matched by her partial isolation among her peers in Mozambique, her partial involvement in social issues in her country, and her partial non-acceptance of the word "femi- 
nist." For example, in an interview to the online newspaper Madeirazinco Chiziane tactically avoids to be called a "feminist": "Estou-me nas tintas... que o chamem. Eu sou uma mulher e falo de mulheres, então eu sou feminista? É simplesmente conversa de mulher para mulher, não é para reivindicar nada, nem exigir direitos disto ou daquilo" (Manjate 2002). Chiziane's partial non-acceptance of the word "feminist" reflects more than an awareness of the concept's perceived "blindness" to the complexities of women's class, race, sexuality and ethnicity in situated contexts. Full contestation or acceptance of this word might indeed endanger Chiziane's legitimization as a Mozambican woman writer not only outside Mozambique (as an "authentic" African woman writer), but also inside (as a Mozambican woman writer).

Osório has suggested that Chiziane's non acceptance of the term "feminist" may have to do with the limits imposed by the environment where she writes and with the audience to whom she writes: "Até que ponto é que ela pode deixar de ser vista como escritora moçambicana se ela se declarar feminista?" (Martins and Tavares 2008b). Chiziane's acceptance of the tag "feminist" might therefore endanger the growing popularity of her novels - and of herself. Although most Mozambicans have not bought or indeed read most of her novels, Chiziane's work is gaining popularity throughout Mozambique. The initial feelings of resistance that prevented her from "being accepted as a woman writer in Mozambique and being taken seriously by the AEMO" (Owen 2007: 216), are gradually disappearing. The number of theses recently dedicated to Chiziane's novels presented by final year students to obtain the degree in Linguistics and Literature at the Universidade Eduardo Mondlane in Maputo shows how academia in Mozambique is slowly opening up to her work. ${ }^{11}$

\footnotetext{
${ }^{11}$ During my visit to the Eduardo Mondlane University, I found ten finalyear projects dedicated to the work of Paulina Chiziane. The following are all theses presented by final year students to obtain the degree in Linguistics and Literature at the Universidade Eduardo Mondlane in Maputo: Eduardina Menezes dos Santos Gamito, "A mulher e o imagi-
} 
The negative reactions to the publication of her previous novel O Sétimo Juramento (Chiziane 2000) in Maputo led Chiziane to launch Niketche in Portugal instead of Mozambique. As the author wryly notes, people at home were taken aback by the positive reactions to the publication of Niketche in Portugal. The Portuguese book launch ended up working as a wise promotional strategy, boosting the popularity of Chiziane in Mozambique. The publication of Niketche also made the sales of her previous novels rise. As Paulo Guerreiro notes in an unpublished interview: "com o Niketche e o Alegre Canto da Perdiz, as pessoas retornaram à procura do resto dos livros" (Martins and Tavares 2008c). Chiziane commented that she has heard women in the local markets in the outskirts of Maputo where she lives discussing taboo issues such as women's sexuality through reference to the book:

Encontrei vendedoras de mercado, mulheres comuns a ler... divertiam-se, riam-se das partes mais quentes do Niketche,... Passado algum tempo alguém olha para mim e diz: És tu! Eu? O que é que foi? Foi você que escreveu este livro. Fiquei simplesmente espantada. Então, isso não acontece com todas as pessoas. Não, em Moçambique, não. Eu consegui chegar a essas pessoas de diferentes estratos sociais. A minha linguagem é muito fácil, as histórias são simples, e as pessoas sentem-se reflectidas. (Martins and Tavares 2008a)

nário tradicional em Paulina Chiziane" (Maputo 2004). Supervisor: Dr. Gilberto Matusse; Hermínia Fernanda dos Santos Muchanga, "A fauna em O Sétimo Juramento de Paulina Chiziane" (Maputo 2006). Supervisor: Dr. Almiro Lobo; Tomé Alexandre de Andrade, "Influência dos mitos e lendas na obra O Sétimo Juramento, de Paulina Chiziane" (Maputo 2005). Supervisor: Dr. Gilberto Matusse; Zacarias André Sitoe, "O universo masculino em Niketche, de Paulina Chiziane" (Maputo 2006). Supervisor: Dr. Almiro Lobo; Elsa Paula Mutembra Cumaio, "Interpretação da obra de Paulina Chiziane" (Maputo 2005). Supervisor: Dr. Almiro Lobo; Aissa Nuro, "O quotidiano das personagens femininas na obra Niketche, de Paulina Chiziane" (Maputo 2006). Supervisor: Dr. Francisco Noa; Fernando Miguel Machai, "Projecção do Espaço suburbano na ficção de Paulina Chiziane e Aldino Muianga" (Maputo 2006). Supervisor: Dr. Francisco Noa; Celeste Berta Sumbana, "A personagem Sarnau em Balada de Amor ao Vento, de Paulina Chiziane" (Maputo 2004); Silvio João Kandiyane Candido, "A morfologia e a sintaxe do mito em O Sétimo Juramento" (Maputo 2004). Supervisor Dr. Almiro Lobo. 
In the above citation, Chiziane not only demonstrates the level of popularity of Niketche, which she attributes to her ability as a writer to reach popular sensitivities, but also her personal level of popularity - her own particular form of celebrity status. To have been recognized by the women living in the neighborhood, exactly where she decided to "marginalize" herself, says something about Chiziane's discourse on her self-inflicted "isolation" and lack of "popularity" in Mozambique, often justified by means of her "dangerous"-because problematic-writing. From the early days at the AEMO when she had to fight (both metaphorically and literally) for her own space, to her present situation of relative comfort and power as a legitimized writer in her country and abroad, Chiziane has managed to take advantage of her initial marginalization as Mozambique's first woman novelist, by staging that marginal status. The writer's decision to build her home in the outskirts of Maputo, far away from "the action," proves the extent to which this staged marginalization is conscious and intended: "Não é sem razão que eu escolhi este canto, porque estou muito longe de tudo e de todos. Aqui não é muito fácil chegar" (Martins and Tavares 2008a). Chiziane's non-participation in the public sphere in Mozambique, vehemently stressed by Osório, corroborates this view:

\footnotetext{
Porque é que a Paulina não aparece nas marchas que as mulheres fazem [em Moçambique]?... Ela mantém-se na sua... não tem nada a ver com isso, como se a sua escrita saísse das suas sensibilidades extra-sociais... Mas não actua, nem sobre, por exemplo, situações de violação clara dos direitos das mulheres... Ela não se manifesta, não aparece em nada... Ela gosta de sentirse como observadora, como outsider. O papel que ela está a representar, qual é? (Martins and Tavares 2008b)
}

The answer to Osório's question comes from Chiziane herself. As a writer, she adopts the role of the rebel: "Eu acho que sou muito rebelde. Busco coisas que ninguém busca" (Martins and Tavares 2008a). When being interviewed, the author significantly markets her work as "daring" and "dangerous" ("Ser escritora é uma ousadia" 
[Manjate 2002]). Chiziane's literary output has contributed enormously to counter-narrating the masculine discourses that have shaped the building of the Mozambican nation. But, as a closer look into Niketche shows, the author does not engage in open-ended contestation. Instead, her contestation tends to stay within well-defined limits, so as to maintain her writing "out of trouble." In many respects, Chiziane's self-perception matches that of the marginalized writer or "oppositional intellectual" who, according to Edward Said in Representações do Intelectual, agrees to pay the price of marginalization for generating controversy, as "indivíduos em conflito com a sua sociedade e, em consequência, inconformados e exilados no que se refere aos privilégios, ao poder e às honrarias" (Said 2005: 60). However, Chiziane's perception of her own dimension as a writer in her country communicates another image of the author-one of consonance, rather than dissonance, with mainstream readerships: "Mas também tem esse lado popular. Todo o mundo lê e fica feliz. Então, no meio das pessoas pouco ligadas a este mundo complexo de belas palavras, os meus livros são bem aceites e vão conquistando cada vez mais espaço... Mas sinceramente, acho que tenho uma situação bastante confortável" (Martins and Tavares 2008a, my emphasis). Chiziane's use of the word "comfortable" here is symptomatic of the fact that she is no longer in the position of the "outsider" as she once was. A certain amount of privilege and power has been achieved which does entirely not conform to her discourse of "exile" (whether real or simply metaphorical).

To conclude, Chiziane's imagination of Mozambique may be partially dictated from within European knowledge systems, and it may be highly contingent on an effort to contest that is never fully materialized, but that does not mean that her novel leaves the dominant system intact. Recently, the Mutumbela Gogo Company adapted the novel to the stage producing a show that was a great success in Maputo. Chiziane complains that the novel's adaptation to the theatre was done almost behind her back, which demonstrates the extent to which the book is being appropriated in Mozam- 


\section{Niketche}

bique to meet local people's requirements (Martins and Tavares 2008a). It is by focusing on the ways in which Mozambicans make sense of Niketche - the many ways in which "the power of the book" (Harries 2001: 420) (and not necessarily the book itself) is read in Mozambique - that the novel's transgressive potential can be best described, a potential which no dominant system can direct or control. Like at the beginning of the century when the Swiss mission converts were taught to read and write, but learned the skills in different ways, reworking the missionaries' stories and their anthropological authority over the world into their own cosmos and in support of local practices (Harries 2001: 417), so domestic audiences today are drawing on local systems of knowledge and communication in their domestic consumption of Niketche in ways that emphasize the book's promotion of gender issues, local practices, regional specificities, and national dialogue. That is, perhaps, Niketche's most important — but less visible — story of success. ${ }^{12}$

\section{Works Cited:}

Ahmed, Sarah. Strange Encounters:Embodied Others in Postcoloniality. London: Routledge, 2000.

Aristophanes. Lysistrata. Perseus DigitalLibrary. Jack Lindsay (ed). Tufts University [c. 411]. $<$ http://www.perseus.tufts.edu/hopper/home $>$ [accessed 18 May 2009]

Campos, Sandra. "Corporeal Identity: Representations of female sexuality and the body in the novels of Paulina Chiziane." Sexual/Textual Empires: Gender and Marginality in Lusophone African Literature. Eds. Hilary Owen and Phillip Rothwell. Lusophone Series 2. Bristol: HiPLA. 2004.137-154.

\footnotetext{
${ }^{12}$ I would like to thank Professor Hilary Owen and a blind reviewer for comments and suggestions that helped shape the final version of this paper. This paper is part of a doctoral project financed by Fundação para a Ciência e a Tecnologia. An earlier version of this article was presented as a paper at the APSA conference held in Yale in 2008
} 
Chiziane, Paulina. Balada de Amor ao Vento. Lisboa: Caminho, 2003.

---. Niketche: Uma História de Poligamia. Lisboa: Caminho, 2002.

---. 2000. O Sétimo Juramento. Lisboa: Caminho.

---. 1999. Ventos do Apocalipse. Lisboa: Caminho.

Cruz e Silva, Teresa. Protestant Churches and the Formation of Political Consciousness in Southern Mozambique (1930-1974). Bern: P. Schlettwein Publishing, 2001.

Davison, Jean. Gender, Lineage and Ethnicity in Southern Africa. Boulder: Westview Press, 1997.

Harries, Patrick. "Exclusion, classification and internal colonialism: the emergence of ethnicity among the Tsongaspeakers of South Africa." The Creation of Tribalism in Southern Africa. Berkeley and Los Angeles: University of California Press. 1989. 82-117.

---. Junod e as Sociedades Africanas: Impacto dos Missionários Suíços na África Austral. Maputo: Paulinas Editorial, 2007.

---. "Missionaries, Marxists and Magic: Power and the Politics of Literacy in South East Africa." Journal of Southern African Studies. 27.3 (2001): 405-427.

Huggan, Graham. The Post-colonial Exotic: Marketing the Margins. London: Routledge, 2001.

Junod, Henri-Alexandre. The Life of a South African Tribe. Vol 2. London: MacMillan, 1927.

Manjate, Rogério. "Ser escritora é uma ousadia!".

Interview to Paulina Chiziane. Madeirazinco. 10 April 2002. $<$ http://passagensliterarias.blogspot.com/2008/01/entrevistapaulina-chiziane.html $>$ [accessed 3 March 2009].

Martins, Ana and Maria Tavares. Unpublished interview to Paulina Chiziane. Maputo. 19 August 2008 (a).

---. Unpublished interview to Conceição Osório. Maputo. 21 August 2008 (b).

---. Unpublished interview to Paulo Guerreiro. Maputo. 5 August 2008 (c).

Morrison, Blake. "A 2,500-year-old sex ban." The Guardian. September 102007. 
Ngoenha, Severino. “Os Missionários suíços face ao nacionalismo moçambicano: entre a tsonganidade e a moçambicanidade." Lusotopie (1999): 425-436.

Owen, Hilary. Mother Africa, Father Marx: Women's Writing of Mozambique 1948 - 2002. Lewisburg: Bucknell University Press, 2007.

Rosário, Lourenço. "Niketche: O Existencialismo no Feminino." Singularidades II. Lisboa: Texto Editores, 2007. 115-18.

Sheldon, Kathleen. Pounders of Grain: A History of women, work and politics in Mozambique. Heinemann: Portsmouth, 2002.

Said, Edward. Representações do Intelectual: As conferências Reith de 1993. São Paulo: Companhia das Letras, 2005. 